\title{
Un espoir de vaccin contre le virus Ebola
}

Les virus responsables de fièvres hémorragiques sont source d'inspiration, plutôt pauvre, pour le cinéma. Dans les films, ils tuent sauvagement, d'abord la population ensuite les méchants. L'humanité est sauvée par le savant héros qui développe un vaccin en quelques jours. Qu'en est-il en réalité? Peut-on espérer, un jour prochain, voir disparaître ces infections répétées aussi spectaculaires que dramatiques?

Le virus Ebola et le virus de Marburg appartiennent à la famille des filovirus. Ils provoquent des fièvres hémorragiques avec un très fort taux de mortalité pouvant atteindre $90 \%$ des cas. En quelques jours, apparaissent fièvre, vomissements et diarrhées puis surviennent les hémorragies. Généralement, les patients meurent une dizaine de jours après le début des symptômes. Ces virus sont très contagieux et peuvent se transmettre par simple contact physique avec des individus infectés, une poignée de main suffit. La première apparition certaine d'Ebola date de 1976. On l'a retrouvé au Soudan, au Zaïre, en O uganda et au Gabon, responsable de flambées d'infection subites mais de courte durée $\left(\mathrm{m} / \mathrm{s} 1999, \mathrm{n}^{\circ} 10\right.$, p. 1168). L'amplitude et la durée des épidémies récentes dues aux virus Ebola et de Marburg suggèrent un mode de transmission répété, peutêtre une conséquence de la transformation des écosystèmes qui favorise le contact entre l'homme et le réservoir naturel encore inconnu.

Avec un tel tableau clinique et épidémiologique, la vaccination semble la stratégie de lutte la plus appropriée. Les mesures de sécurité associées au développement d'un tel vaccin sont maximales: pas de virus atténué ni même tué et manipulation dans un laboratoire de haute sécurité de type P4. Deux équipes américaines ont contourné ce problème [1]. Ces chercheurs ont réussi à protéger des macaques cynomolgus contre le virus Ebola en leur injectant de I'ADN viral puis, dans une première injection de rappel, un vecteur adénoviral codant pour des protéines virales. L'immunisation génétique agit à la fois sur la réponse immunitaire cellulaire et humorale et a déjà été testée avec plusieurs agents pathogènes [ 2 5]. On pense que les cellules transfectées par I'ADN injecté présentent au système immunitaire des protéines virales néosynthétisées comme s'il s'agissait d'une réelle infection et que cela s'effectue dans un contexte d'immunostimulation provoqué par la seule présence de l'ADN lui-même $[6,7]$. L'injection de rappel avec un adénovirus recombinant incapable de se multiplier mais permettant la synthèse de la glycoprotéine d'Ebola a pour but de stimuler encore plus la production d'anticorps. En effet, la protection des rongeurs contre le virus Ebola est proportionnelle à la quantité d'anticorps produits par les animaux.

Les auteurs ont d'abord prouvé l'efficacité de leur stratégie vaccinale chez le cobaye avant de vacciner les primates. Les essais chez le macaque ont une meilleure valeur prédictive car ces singes peuvent être infectés directement avec les souches d'Ebola qui contaminent l'homme et la maladie se développe de manière assez semblable. Les résultats sont spectaculaires. L'immunisation génétique avec de l'ADN d'Ebola codant pour les protéines structurales de plusieurs isolats viraux issus de régions géographiques différentes engendre une forte réponse immunitaire et les primates traités survivent à l'injection d'une dose létale de la souche Ebola Zaïre, le sous-type viral qui entraîne le plus fort taux de mortalité pour I'homme. Cela est très encourageant même si les auteurs n'ont pas étudié en détail les mécanismes de la protection et si la dose test utilisée lors de l'infection post-vaccinale est faible. On ne sait pas en effet si les animaux auraient survécu à une dose infectante plus forte, proche de celle des conditions présumées de l'infection humaine.

Le vaccin humain ne sera pas prêt demain mais la piste semble bonne. D'autant que des singes ont aussi été protégés contre le virus de Marburg à I'aide d'un vaccin à base d'alphavirus modifié [ 8]. La faisabilité d'un vaccin contre les filovirus est donc raisonnablement envisageable.

1. Sullivan NJ, Sanchez A, Rollin PE, Yang Z, Nabel G]. Development of a preventive vaccine for Ebola virus infection in primates. Nature 2000; 408: 605-9.

2. Tang DC, DeVit M, Johnston SA. Genetic immunization is a simple method for eliciting an immune response. Nature 1992; 356: 152-4.

3. UImer JB, Donnelly JJ, Parker SE, et al. H eterologous protection against influenza by injection of DNA encoding a viral protein. Science 1993; 259: 1745-9.

4. Wang B, U gen KE, Srikantan V, et al. Gene inoculation generates immune responses against human immunodeficiency virus type 1 . Proc Natl Acad Sci USA 1993; 90: 4156-60.

5. Sedegah M, Hedstrom R, Hobart P, Hoffman SL. Protection against malaria by immunization with plasmid DNA encoding circumsporozoite protein. Proc Natl Acad Sci USA 1994: 91: 9866-70. 6. Krieg AM, Yi AK, Matson S, et al. CpG motifs in bacterial DNA trigger direct $B$ cell activation. Nature 1995; 374: 546-9.

7. Sato $Y$, Roman M, Tighe $\mathrm{H}$, et al. Immunostimulatory DNA sequences necessary for effective intradermal gene immunization. Science 1996; $273: 352-4$.

8. Hevey M, Negley D, Pushko P, Smith J, Schmaljohn A. Marburg virus vaccines based upon alphavirus replicons protect guinea pigs and nonhuman primates.Virology 1998; 251: 28-37.

\section{Vincent Lotteau}

Inserm U. 503, Immunobiologie moléculaire, École normale supérieure de Lyon, 46, allée d'Italie, 69364 L yon Cedex 07, France. 